\author{
811.163.41'367.622:811.112.2’367.622 \\ 811.163.41'38:070.41 \\ 811.112.2'38:070.41 \\ https://doi.org/10.18485/sj.2020.25.1.27
}

МЛАДЕН Д. ПАПАЗ

Универзитет у Источном Сарајеву

Филозофски факултет

\section{РУЖИЦА ЗЕЉКО-ЗУБАЦ**}

Свеучилиште у Мостару

Филозофски факултет
Оригинални научни рад

Примљен: 15. 10. 2019.

Прихваћен: 15. 01. 2020.

\title{
КОНТРАСТИВНА АНАЛИЗА ИМЕНИЦА СА ИНДИРЕКТНИМ ЕПИСТЕМИЧКИМ ЗНАЧЕЬЕМ У НОВИНСКИМ ИЗВЈЕШТАЈИМА
}

Предмет овог рада јесу именице са индиректним епистемичким значењем које се користе у пропагадне сврхе у процесу извјештавања. Новинар користи поменуте именице у новинским извјештајима с циљем а) увјеравања реципијента у истинитост пропозитивног садржаја или б) дистанцирања од истинтитости пропозитивног садржаја. У овом раду ћемо контрастивном методом указати на сличности и разлике при употреби именица са индиректним епистемичким значењем у новинским извјештајима на српском и њемачком језику.

Кључне ријечи: манипулативна стратегија, девербативне именице, увјеравање, ограђивање, епистемичка модалност.

*mladen.papaz@gmail.com

*** ruzica.zeljkozubac@ff.sum.ba 


\section{1. МАНИПУЛАТИВНА ФУНКЦИЈА ИМЕНИЦА СА ИНДИРЕКТНИМ ЕПИТЕМИЧКИМ ЗНАЧЕЬЕМ У ПРОЦЕСУ САОПШТАВАњА}

У процесу саопштавања новинару стоји на располагању спектар лексичких средстава погодних за манипулативно дјеловање на јавно мњење. Ова лексичка средства имају двоструку улугу у процесу информисања. Новинар, као посредник у процесу саопштавања, користи поменута лексичка средства с циљем а) увјеравања реципијента у истинитост пропозитивног садржаја или б) сопственог дистанцирања од истинтитости пропозитивног садржаја. Језичка средства која се користе у поменуте пропагадне сврхе извјештавања, тј. у сврху манипулативног убјеђивања и ограђивања, јесу лексичка средства која исказују епистемичку модалност. У лингвистичкој литератури епистемичка модалност се грана, уз употребу различите терминологије, на двије поткатегорије епистемичке модалности. Извор модалности је кључни фактор за одређивање поменуте бинарне категоризације епитемичких ставова, те у зависности од поменутог извора модалности, тј. начина на који је новинар дошао до информација, разликују се најчешће тзв. директни и индиректни епистемички ставови. Под директним ставовима подразумијевају се ставови „о садржају пропозиције на основу личног запажања говорника или на основу његовог знања", а под индиректним „знања о пропозицији на основу извјештавања од стране других субјеката" (в. М. Бабић 2012: 116). У овом раду пажњу ћемо посветити, релативно неистраженој теми, односно контрастирању искључиво именица са индиректним епистемичким значењем, с интенцијом утврђивања сличности и разлика при употреби поменутих именица у новинским извјештајима. Индиректну епистемичку модалност изражавају именице које имплицирају да је говорник формирао став на основу информација или извјештавања од стране других људи, наглашавајући при томе говорникову дистанцу и неопредијељеност према истинитости пропозитивног садржаја, односно именице које имплицирају увјерност у истинитост пропозитивног садржаја, уколико се новинар позива на одређени доказни материјал, којим поткријепљује своју информацију. Новинар користи, дакле, поменуте именице са индиректним епистемичким значењем као ограду или као потврду пропозитивног садржаја. Наведене разлике у погледу преузимања неуједначеног степена одговорности према пласираним информативним садржајима заснивају се на различитим илокутивним функцијама ${ }^{1}$. Новинарево увјеравање реципијента у истинитост пропозитивног садржаја одговарало би илокутивној функцији а) тврдње, док би новинарева неопредијељеност према истинитости пропозитивног садржаја одговарала илокутивној функцији б) саопштења с оградом. Илокутивна фун-

${ }^{1}$ Детаљније о разликама и карактеристикама илокутивних функција код П. Пипер и др. (2005: 1012). 
кција тврдње подразумијева поткрепљење пропозитивног садржаја одређеним доказним материјалом, с циљем потврђивања истинитости и аутентичности пропозитивног садржаја, док се илокутивном функцијом саопштења с оградом пропозитивни садржај квалификује као непоуздана информација преузета из неког неодређеног, анонимног извора.

\section{1. Анализа корпуса}

Приликом анализе корпуса сачињеног од преко стотину новинских извјештаја ексцерпираних из дневних новина (Политика, Глас Српске, Сиддоче цајтунг (Süddeutsche Zeitung) и Франкфуртер аллгемајне цајтунг (Frankfuter Allgemeine Zeitung)) најприје ћемо дескриптивно-аналитичком методом идентификовати именице са индиректним епистемичким значењем које новинар користи с циљем а) увјеравања реципијента у истинитост пропозитивног садржаја или б) дистанцирања од истинитости пропозитивног садржаја, описати њихову синтаксичку функцију и морофсинтаксичке карактеристике за језички пар српско-њемачки, те у закључку контрастивном методом указати на сличности и разлике при употреби поменутих именица у новинским извјештајима.

\section{2. УПОТРЕБА ИМЕНИЦА СА ИНДИРЕКТНИМ ЕПИСТЕМИЧКИМ ЗНАЧЕЊЕМ У НОВИНСКИМ ИЗВЈЕШТАЈИМА}

По учесталости реализације најфреквентнију скупину именица у функцији индиректне епистемичке модалности, у новинским извјештајима на њемачком, као и на српском језику, чине девербативне именице 2 . Ову скупину именица са индикретним епистемичким значењем представљају експлицитни или имплицитни деривати настали најчешће од глаголских основа из скупи-

${ }^{2}$ O карактеристикама декомпонованих предиката више код М. Радовановић (1977) и J. Максимовић (2016). У дериватологији постоје различита тумачења девербативних именица. Тако се често идентични и/или слични глаголски облици (основе) приписују различитим творбеним обрасцима. Прегледом референтне граматичке литературе, можемо закључити да се у њемачком језику може подвући јасна граница између ранијих (В. Флајшер: 1969) и новијих (Флајшер/Барц 1995), Е. Доналис (2005) тумачења девербативних именица. Битна разлика уочљива је у различитом схватању категорије конверзија. Дефиниција конверзије схваћена је много шире у новијим издањима, и не своди се само на поименичавање инфинитивне основе глагола, него обухвата и друге глаголске основе, као што су презентска и претеритска, а које су се у старијим издањима сврставале у имплицитну деривацију са или без аблаута (в. В. Флајшер 1969). Интересантно је да се кореспондентни облици у сербокроатистици сврставају у експлицитну деривацију са тзв. $\theta$ морфемом (в. С. Бабић 2002: 326-328; И. Клајн 2003: 211-215) или са суфиксом -a, код именица које теже да постану семантички независне, иако су етимолошки настале од глагола, као над $\underline{a}$, сумњ $\underline{a}$ (в. И. Клајн 2003: 17). 
не глагола саопштавања (ерба диценди), чије семантичко значење именица задржава, с разликом да се новинару процесом номинализације отвара могућност да избјегне навођења модалног извора, као што илуструје сљедећа реконструкција са глаголом тврдити:

1. Саша Јањић, технички руководилац флотације, тврди да је јаловиште потпуно обезбећено,..$(П о, ~ 36474,29.05 .2015,12) .1$. а) Тврдње да је јаловиште потпуно обезбећено,

Номинализација као творбени процес доприноси деперсоналиазацији и анонимизацији модалног извора, а самом саопштењу даје тежину званичности и укида осјећај субјективности. Девербативне именице као резултат поименичавања и других творбених образаца насталих од глаголске основе сматрају се једном од главних одлика новинских извјештаја, који се у лингвистичкој литератури сврставају у устаљене, стеротипне конструкције. Аксић (2014: $263)$ номинализацију види као знак модернизације и глобализације језика, те се помоћу ње званични говор дистанцира од свакодневног.

\section{1. Именице са индиректним епистемичким значењем у функцији саопштења с оградом у новинским извјештајима}

С обзиром да девербативне именице, на што смо претходно указали, не исказују податке о примарном извору информације, ова скупина именица јавља се у новинским извјештајима најчешће у илокутивној функцији саоnuтена с оградом. Новинар употребом именица са индиректним епистемичким значењем квалификује пропозитивни садржај као информацију из неког неодређеног извора, искључује себе као извор информације и изражава свој недостатак опредијељености према истинитости пропозитивног садржаја. Девербативне именице имплицирају новинареву посредничку улогу у процесу саопштења, док примарни извор информације остаје анониман, што за посљедицу има мањи степен поузданости и аутентичности пропозитивног садржаја. По учесталости реализације у одабраном корпусу на српском језику најчешће су реализоване девербативне именице тврдю $a^{3}$, рјеђе прича 4 , односно информација $^{5}$, именице страног поријекла са посуђеним и адаптираним суфиском, које регирају, као и њихови глаголски еквиваленти (тврдити, информисати,

\footnotetext{
${ }^{3}$ тврдња - оно шито неко тврди, износи као истину (РСЈ 2007:1305).

${ }^{4}$ прича - 2. а) причање, приповедање, саопштавање; б) (обично у множини) непроверено казивање, гласине (РСЈ ибид: 1053).

${ }^{5}$ информација - податак о некоме или нечему, обавештење, саопитење, извјештај (РСЈ ибид.: 478);
} 


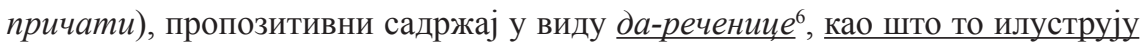
сљедећи примјери:

\section{Саопштење с оградом}

1. Тврдње да су на Земунскомкеју лабудови оковани ледомида је велики бројњих угинуо нису потврдиле надлежне институщије. (По, 7058, 11.01. 2017, 14).

2. „У овом случају специјални тужилац за ратне злочине требало је да ову истрагу приведе крају јер имамо информацију да су докази који су послати на вештачење америчком ФБИ већ стигли тужилаштву и сматрам да нема других разлога за додатна померања у овом поступку”, рекао је Васић. (По, 36474, 29.05. 2015, 9).

3. Чули смо и причу да се и овде умешала страначка политика, па нам се један пожали да је заобиђен због тога што су „плаћени чистачи” закључили: „нека њега, нека чека-комуњара”. (По, 7058, 11.01. 2017, 13).

Девербативне именице јављају се у претходним примјерима најчешће у функцији реченичних допуна, у функцији субјекта или објекта у акузативу, са реализованим пропозитивним садржајем у облику да-реченице у функцији атрибута (Тврдња $\rightarrow$ да). Овакве конструкције специфичност су новинских извјештаја на српском језику.

У новинским извјештајима на њемачком језику именице са индиректним епистемичким значењем јављају се ријетко саме у функцији реченичних чланова и код њих до изражаја долази честа морфосинтаксичка зависност, с обзиром на то да се по учесталости реализације јављају најчешће као синтаксички сателити приједлошких фраза. Поменуте приједлошке фразе јављају су и у новинским извјештајима на српском језику, међутим, са знатно нижом фреквенцијом јављања у поређењу са њиховом дистрибуцијом у новинским извјештајима на њемачком језику. Један од модела који се показао врло фреквентним у новинским извјештајима, јесте конструкција са приједлогом " $n a c h /$ према + именичка фраза". У оваквим приједлошким фразама приједлог регира заправо именицу са индиректним епистемичким значењем, квалификујући садржај пропозиције као информацију преузету из другог извора. Приједлошке фразе које регирају именице са индиректним епистемичким значењем као синтаксички зависне сателите репрезентују сљедећи примјери:

${ }^{6}$ У ексцерпираним примјерима преузетим из нашег корпуса обиљежили смо и подвукли пропозитивни садржај два пута ради прегледности и јаснијег истицања различитих облика реализације. 


\section{Саопштење с оградом}

4. Према незваничним информацијама ухапшени су Никола Нешковић (26) из Билеће, Јово Голо (51) из Требиња, Александар Ивковић (30) из Билеће, Фатима Авдагић (51) и Јасмин Сијамић (28) из Сарајева. (ГС, 13706, 10.04.2015, 12)

5. Према првим наводима италијанске полиције, разлог за пуцњаву било је суђење о банкроту,.... (ГС,13706, 10.04.2015,19)

6. Према тврдњи лекара, метак је несрећну жену погодио тачно у срще, па јој није било спаса. (По, 7058, 11.01.2017, 9)

7. Према њеним речима, све то утиче демотиващионо. (По, 36474, 29.05.2015, 11)
1. Nun hat die Herrscherfamilie aus Dubai über ihre Investment Corperation of Dubai (ICD) nach Informationen dieser Zeitung kräftig in das Finanz-Start-up investiert, das im Kern eine App anbietet. (FA, 9, 11.01.2017, 24)

2. Der 27. Juli ist deshalb so wichtig, weil nach offizieller Darstellung von VW der Vorstand erst Wochen später von den Manipulationen erfahren haben soll. (SZ, 9, 11.01.2017, 2)

3. Nach Auskunft des Bundesinneministeriums wird derzeit nur sehr selten Abschiebhaft angeordnet. (FA, 9, 11.01. $2017,1)$

Максимовић (2016: 268) поменуте приједлошке фразе назива ,,ауторска дидаскалија без предикација", с обзиром на то да је глагол изостављен, а да се на његовом мјесту јавља девербативна именица као подређени члан приједлошке фразе. Поменуте приједлошке фразе толико су фреквентне у новинским извјештајима, нарочито на њемачком језику, да се у лингвистичкој литератури називају и шаблонским, језичким калупима (в. М. Катнић Бакаршић 1999: 59-60). У наведеним приједлошким фразама пропозитивни садржај јавља се уз девербативне именице у види тзв. неуведених тзв. $\underline{X \Pi T C-p е ч е н и ц a^{7}}$ (npeма тврдюи $\rightarrow$ ропозитивни садржај), за разлику од српског језика гдје се пропозитивни садржај уз девербативне именице јавља најчешће у функцији атрибута у виду да-реченице.

Међутим, у одабраном корпусу пропозитивни садржај није увијек реализован и често је изостављен из површинске структуре уз девербативне именице. Разлог за ово изостављање је чињеница да новинар користи девербативне именице и као референцијалне, деиктичке елементе који упућује на дијелове претходно споменутог исказа, као у сљедећим примјерима:

${ }^{7}$ Скраћеницу ХПТС преузели смо од У. Енгела (2004) за Haupsatzförmige Ergänzung, тј. неуведену реченичну допуну која је по структури идентична главној реченици. 


\section{Саопштење с оградом}

8. [зјава да.... $] \leftarrow$ Изјава премијера Албаније је, како је додао, у супротности са више пута изреченим опредељењем Србије и Албаније за развој добросуседства, сарадње, узајамног разумевање и заједничке будућности у Европској унији-наводи се у саопштењу. (ГС,13706, 10.04.2015, 15)

9. [зјава да....] $\leftarrow$ Изјаве Вилцове су у складу са дугогодишњом квазиколоквијалном праксом успостављања 'суверенитета' БиХ и разлог више због којег је за Бања Луку важно да се не активира Акциони план за чланство у НАТО (МАП), јер РС би морала да свира по нотама НАТО-а. (По, 7058, 11.01.2017, 4).
4. [Die Aussage, dass..] $\leftarrow$ Die Aussage der beiden Kronzeugen, die von der US-Justiz jetzt teilweise veröffentlicht wurden, sollen Winterkorn bekannt sein. (SZ, 9, 11.01. 2017, 1)

5. [Die Aussage, dass..] $\leftarrow$ Die Aussage ist insofern nicht völlig eindeutig, als sie sich auf das 2020er Ziel oder den gegenwärtigen Planstand beziehen soll. (FA, 9, 11.01.2017, 21)

6. [Die Aussage, dass..] $\leftarrow$ Insbesondere die Aussage des Kronzeugen Nummer 1 bei der US-Justiz steht dem entgegen. (SZ, 9, 11.01.2017, 1)

Новинар користи у претходним примјерима именице Aussage 8 изјава које имплицитно указују на новинареву посредничку улогу, као референцијалне, деиктичке елементе који упућује на дијелове претходно споменутог исказа. Поменуте девербативне именице упућује на неизречени пропозитивни садржај који је претходио у контексту, али не преноси његов садржај у облику да-реченице (ъем. dass-реченице), што доприноси економичности и повезаности самог саопштења.

У њемачком језику умјесто пропозитивног садржаја уз именице које изражавају индиректну епистемичку модалност (Debatte ${ }^{10}$, Gerücht $^{11}$, Kommentar $^{12}$, Spekulation $\left.^{13}\right)$ и које указују на новинареву посредничку улогу, реализоване

\footnotetext{
${ }^{8}$ Aussage-1. geäußerte Meinung, Feststellung, Urteil (Дуден 1996: 188) - (Изречено мииљење, став, оијена), (Превод дефиниција у нашем раду: М. Папаз).

${ }^{9}$ изјава- 1. оно што се јавно изјави, саопшти, каже (писмено или усмено), исказ, званично саопитене (PCJ 2007: 456).

${ }^{10}$ Debatte-a) lebhafte Diskussion, Auseinandersetzung, Streitgespräch (Дуден 1996: 322). (Живахна дискусија, расправа, свађа).

${ }^{11}$ Gerücht- etwas, was allgemein gesagt, weitererzählt wird, ohne dass bekannt ist, ob es auch wirklich zutrifft (Дуден 1996: 594). - (Нешто, ито се уопштено каже, прича, без да се зна да ли је заиста истинито).

${ }^{12}$ Kommentar -2. Kritische Stellungnahem, zu einem aktuellen Ereignis oder Thema (in Presse, Rundfunk o. Ä. (Дуден 1996: 594). - (Критични став о неком актуелном догађају или теми (у штампи, радију и сл..).

${ }^{13}$ Spekulation- auf bloßen Annahmen, Mutmaßungen beruhende Erwartung, Behauptung, dass etwas eintrifft (Дуден 1996: 1429). - (На претпоставкама засновано очекивање, тврдње да ће се нешто догодити).
} 
су често и приједлошке фразе као допуне, које не исказују пропозитивни садржај, већ само ближе одређују тематику саопштења, као што то показују сљедећи примјери:

\section{Саопштење с оградом}

7. Die Debatte über die Machtverteilung zwischen Verwaltung und Professoren tobt allerdings, nicht nur hierzulande, sondern auch an den besten amerikanischen Universitäten. (FA, 9, 11.01.2017, N3)

8. Die Gerüchte über Alkoholexzesse und Affären des Dreiundfünfzigjährigen hielten dagegen an. (FA, 9, 11.01.2017, 7)

9. Folgerichtig daher sein entspannter Kommentar zum britischen Referendum. (FA, $9,11.01 .2017,17)$

10. Die Spekulation um Winterkorn und Diess sind daher nicht erstaunlich. (FA, 9, 11. $01.2017,15)$

Поменуте именице Spekulation (спекулација) и Gerücht (трач) специфичне су и због своје семантике, с обзиром на то да не указују само на новинареву посредничку улогу у процесу преношења информација, него имплицитно указују и на неопузданост пропозитивног садржаја који се преноси.

\section{2. Именице са индиректним епистемичким значењем у функцији тврдње}

Именице са индиректним епистемичким значењем могу, осим истицања новинареве посредничке улоге у процесу саопштавања, да изражавају и експлицитне доказе за одређени пропозитивни садржај када се јављају у илокутивној функцији тврдње. Новинар користи именице из ове скупине како би указао на чињеницу да је формирао свој став на основу експлицитних доказа. Именице са индиректним епистемичким значењем у илокутивној функцији тврдње представљају, такође, најчешће девербативне именице настале, већином експлицитном или имплицитном деривацијом од глаголске основе односно именице страног поријекла са посуђеним и адаптираним суфиксима из латинског језика ${ }^{14}$. У анализираним новинским извјештајима новинар употребом именица са поменутом илокутивном функцијом тврдње указује на доказе/изворе модалности на основу којих је темељио своје ставове. По учесталости реализације у функцији тврдње у новинским извјештајима на српском језику најфреквентнија је именица чињеница ${ }^{15}$, која имплицира да је

${ }^{14}$ Детаљније о страним суфиксима у српском језику код И. Клајна (2003: 218-253).

${ }^{15}$ чињеница - оно ито је искуством потврђено да стварно постоји или да се догађа, истинит, стварни догађај, истинита, стварна појава, факат (РСЈ 2007: 1517). 
пропозитивни садржај у виду да-реченице општепозната, неупитна истина, за које постоје неоспориви, свима доступни, докази. Њен преводни еквивалент у њемачком језику, сложеница ${ }^{16}$ Tatsache $^{17}$ која такође регира пропозитивни садржај у виду да-реченице у функцији атрибута, има знатно нижу фреквенцију у новинским извјештајима на њемачком језику. Употребу поменутих именица у новинским извјештајима илуструју сљедећи примјери:

\begin{tabular}{|c|c|}
\hline \multicolumn{2}{|c|}{ Тврдња } \\
\hline $\begin{array}{l}10 . \text { Чињеница да је берлински нападач управо } \\
\text { био у вези са једном таквом салафистичком } \\
\text { групом утицала је на немачке политичаре да } \\
\text { у јавности брзо промене своје мишљење. (По, } \\
7058,11.01 .2017,3) \\
11 . \text { Чињеница је да ова власт није запошљава- } \\
\text { ла нове људе. (По, } 36474,29.5 .2015,11)\end{array}$ & $\begin{array}{l}\text { 11. Die Tatsache, dass seine eigene Mutter } \\
\text { einen kroatischen Hintergrund aufweist, spart } \\
\text { er beim Schreiben lange aus. (FA, 9, } 11.01 . \\
\text { 2017, N3) } \\
\text { 12. Die Leverkusener ziehen Trost aus der Tat- } \\
\underline{\text { sache, }} \text { dass die Niederlage auf großer Bühne } \\
\text { immer knapper wird. (SD, 82, 10.04.2015,33) }\end{array}$ \\
\hline
\end{tabular}

Претходни примјери показују јасно да се именице чињеница/Tatsache при исказивању илокутивне функције тврдње јављају са идентичном синтаксичком структуром у српском и њемачком језику када изражавају став увјерености у односу на пропозитивни садржај у облику да-реченице. Пропозитивни садржај се употребом поменутих именица приказује као општепозната, неупитна истина за коју постоје свима доступни докази, што за циљ има повећање вјеродостојности и аутентичности информације.

Осим поменутих именица, илокутивну функцију тврдюе у одабраном корпусу често изражава и девербативна именице $\underline{A n g a b e}^{18}$, односно њен еквивалент у српском језику, именица податак. Међутим, употреба поменутих именица разликује се на синтаксичком плану. Поменуте именице јављају се у новинским извјештајима са различитим синтаксичким функцијама и са различитом морфосинтаксичком стуктуром. Девербативна именица Angabe јавља се у новинским извјештајима на њемачком језику искључиво као подређени сателит приједлошких фраза и не регира пропозитивни садржај, док се именица nодатак ${ }^{19}$ у српском језику јавља самостално и регира пропозитивни садржај у облику да-реченице, што илуструје сљедећи примјер:

${ }^{16}$ У овом раду анализирали смо сложенице према Е. Доналис (2005) и В. Флајшер/И. Барц (1995) гдје се у сложенице сврставају све творбене конструкције, чији се појединачи дијелови јављају самостално у језичкој употреби, попут Mitbruder, Beiprogramm (в. Доналис 2005: 74), Mitbesizter и сл. (в. Флајшер/Барц 1995: 117).

${ }^{17}$ Tatsache-Wirklicher, gegebener Umstand, Faktum (Дуден 1996: 1517). - (Стварне, дате околности, факти).

${ }^{18}$ Angabe-1. Aussage, Auskunft, Information (Дуден 1996: 109). - (Изјава, обавјештење, информација).

${ }^{19}$ податак- чињеница која је у стварној вези с нечим, која се нечега тиче (и може помоћи у његовом проучавању, разумјевану и сл.) (РСЈ 2007: 946). 


\section{Тврдња}

11. Колико је погрешио у процени можда најбоље показује податак да је данас удео ,ајфона” на тржишту смартфона 11,5 одсто, а „Мајкрософтовог" телефона 0,4 одсто. (По, $37057,10.01 .2017,23$ )

12. Да у овој области има безакоња сваке врсте говори и податак да се у ове високопрофитабилне институције ухљебљују дјеца, рођаци и пријатељи руководилаца тих институција,,...$(Г С, 13706,10.04 .2015,4)$
13. Denn das Nachfüllen ist nach Angaben der Münchner Berufsfeuerwehr die größte Gefahr. (SZ, 9, 11.01.2017, 38)

14. Die Opferanwälte bereiten nach eigenen Angaben jetzt auch Zivilklage in Deutschland und Spanien vor. (SZ, 9, 11.01.2017, 8)

15. UKOG hat nach eigenen Angaben aber keine Fracking-Pläne. (SD, 82, 10.04.2015, 21)

Претходно наведени примјери показују да се девербативне именице Angaben/nодатак у њемачком језику јављају у различитим синтаксичким функцијама, али са истом илокутивном функцијом тврдюе. Девербативна именица Angabe указује на њемачком језику на модални извор и регира пропозитивни садржај најчешће у виду неуведене ХПТС-реченице, што илуструје сљедећа реконструкција: Gefahr.

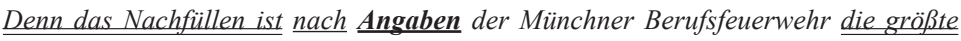

[Angaben] $\rightarrow$ Denn das Nachfüllen ist die gräßte Gefahr.

Пропозитивни садржај: ХПТС-реченица

За разлику од њемачког језика, именица податак не јавља се у српском језику као сателит приједлошких фраза, него самостално као реченични члан. Поред тога, именица податак не пресупонира само на одређени доказ, као у њемачком језику, него и експлицира његов садржај у виду да-реченице, која се јавља у функцији атрибута уз поменуту именицу

И друге девербативне именице $\left(\right.$ Beweis $^{20}$, Bericht $^{21}$, Beleg $^{22}$, Recherchen $^{23}$, Erklärung ${ }^{24}$ ) које се јављају у новинским извјештајима на њемачком језику

${ }^{20}$ Beweis - Nachweis dafür, dass etw. zu Recht behauptet wird, angenommen wird. (Vorbrigen, Anführen einer) Gesamtheit von beständigen Umständen, Sachverhalten, Schlussfolgerungen (Дуден 1996: 253). - (Доказ за то да се нешто оправдано тврди, претпоставља. (Изношење, навођење) цијелокупних околности, чињеница и закључака).

${ }^{21}$ Bericht -Sachliche Wiedergabe eines Geschehens oder Sachverhalts; Mitteilung, Darstellung (Дуден 1996: 237). -(Објективно репродуковање одређеног догађаја или чињенице; саопштење, приказиване).

${ }^{22}$ Beleg-Beweisstück (Дуден 1996: 232). - ( Доказни материјал).

${ }^{23}$ Recherche - 1. Ermittlung, Nachforschung (Дуден 1996: 1223). - (Истрага, истраживање).

${ }^{24}$ Erklärung -2. Mitteilung (offiziele Äußerung), (Дуден 1996: 452). - (Саопштење, званична изјава). 
са индиректним епистемичким значењем, односно илокутивном функцијом тврдюе, јављају се најчешће као синтаксички зависни сателити приједлошких фраза, које експлицитно указују на одређени доказни материјал. Ова скупина девербативних именица најчешће се јавља унутар приједлошких фраза типа: „,nach/in/zum + именичка фраза”. За разлику од њемачког језика именице са

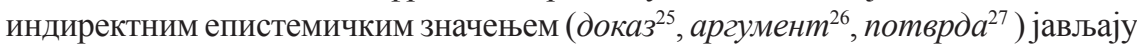
се у новинским извјештајима на српском језику у функцији реченичних допуна са експлицираним пропозитивним садржајем у облику да-реченице, као што илуструју сљедећи примјери:

\begin{tabular}{|c|c|}
\hline \multicolumn{2}{|c|}{ Тврдња } \\
\hline 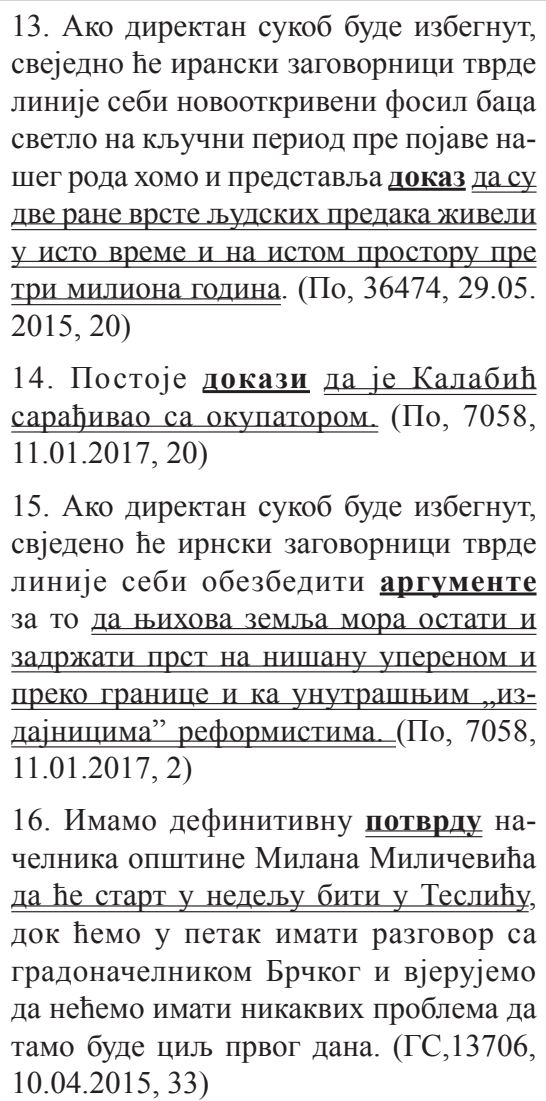 & 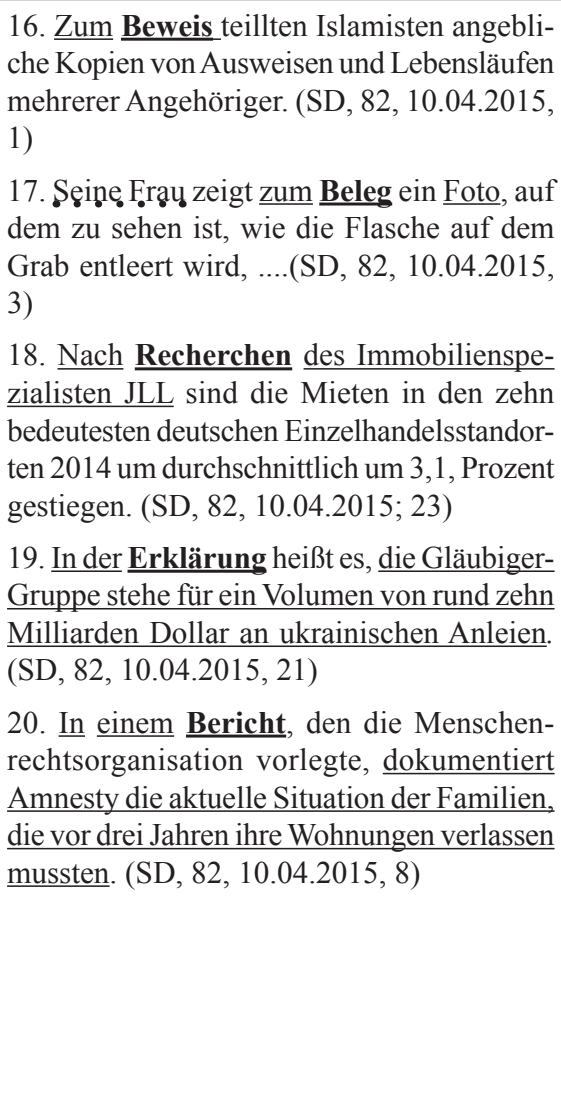 \\
\hline
\end{tabular}

${ }^{25}$ доказ - 1. а) чињеница, односно скуп чињеница, аргумената којима се утврђује истинитост нечега. б) потврда, осведочење нечега (РСЈ 2007: 299).

${ }^{26}$ аргуменат - доказ, доказно средство, образложење, разлог (РС 2007: 42).

${ }^{27}$ потврда - а) реч или гест потврђивања нечега (РСJ 2007: 984). 
Наведене девербативне именице јављају се у њемачком језику као додаци, који указују на различите доказе на које се новинар ослонио приликом саопштавања. По учесталости реализације најчешће се ради о ситуативним додацима (In der Erklärung heißt es...) или финалним додацима (Sẹine Frạu zeigt zum Beleg ein Foto). За разлику од њемачког језика именице са индиректним значењем јављају се у српском језику у функцији реченичних допуна, најчешће допуне у акузативу, и регирају пропозитивни садржај у облику да-реченице. Новинар користи у оба језика поменуте именице као материјал за увјеравање реципијента у истинитост пропозитивног садржаја, с разликом што се у њемачком језику употребом поменутих именица указује на доказни материјал, док се у српском језику јасно експлицира пропозитивни садржај.

Поред поменутих именица које изражавају у новинским извјештајима доказни материјал, новинар указује реципијенту на поузданост и аутентичност информације и употребом именица које пресупонирају визуелну периепщију одређеног пропозитивног садржаја. Најфреквентније именице у новинским извјештајима са индиректним епистемичким значењем које пресупонирају визуелну перцепцију, јесу девербативне именице Beobachter ${ }^{28}$ и Beobachtung, односно именица свједок $\kappa^{29}$ у новинским извјештајима на српском језику, чију употребу илуструју сљедећи примјери:

\begin{tabular}{|l|l|}
\hline \multicolumn{2}{|c|}{ Тврдња } \\
\hline $\begin{array}{l}\text { 17. Још један свједок догађаја пре- } \\
\text { причао је тренутак када је затекао ко- } \\
\text { легу адвоката мртвог на поду суднице. } \\
(\text { ГС, } 13706,10.04 .2015,19)\end{array}$ & $\begin{array}{l}\text { 21. Hahns literaturhistorischer Ausgangs- } \\
\text { punkt ist die } \underline{\text { Beobachtung, dass erst im }}\end{array}$ \\
& $\begin{array}{l}\text { zwanzigsten Jahrhundert Bücher auftauchen, } \\
\text { die niedergeschriebene Träume versammeln, }\end{array}$ \\
& $\begin{array}{l}\text { aber nicht deuten. } \\
\text { 22. Mancher Branchenbeobachter zweifelt } \\
\text { deshalb an der Bedeutung der Detroiter Au- } \\
\text { tomasse- und das, obwohl sich einflussreiche } \\
\text { Automanger positiv zum Autoaustellungsdino } \\
\text { äußerten. (FA, 9, 11.01.2017, 18) }\end{array}$ \\
\hline
\end{tabular}

Поменута именица Beobachtung јавља се у њемачком језику са реализованим пропозитивним садржајем у облику да-реченице, док девербативне

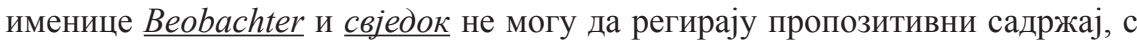

\footnotetext{
${ }^{28}$ Beobachter -jmd., der etw. od. jmdn.beobachtet. (Дуден 1996: 235). - (Неко ко нешто или некога посматра).

${ }^{29}$ сведок - 1. онај који је присуствовао неком догађају и може потврдити његову истинитост, очевидаи (нечега), (РСЈ ибид. : 1199).
} 
обзиром на то да означавају агенсе који имплицитно пресупонирају визуелну перцепцију одређеног пропозитивног садржаја.

Међутим, као што је случај код именица које изражавају доказе, и именице које пресупонирају визуелну перцепцију одређеног пропозитивног садржаја јављају се у новинским извјештајима на њемачком језику најчешће као зависни сателити приједлошких фраза. Новинар употребом поменутих именица указује реципијенту на чињеницу да је примарни извор имао увид у одређени пропозитивни садржај, с намјером да пропозитивни садржај прикаже као провјерен и поуздан, као у сљедећим примјерима:

\section{Тврдња}

23. Nach Beobachtung der Marketingfachleute von Krombacher hat sich auch bei alkoholfreien Bieren das Konsumverhalten in den zurückliegenden Jahren strak verändert. (FA, 9, 11.01.2017, 19)

24. Laut Zeugenaussage schlugen die Flammen bis zu 30 Meter hoch. (SZ, 9, 11.01. 2017, 29)

25. Nach Einschätzung von Beobachtern ist der Krieg in Afgahnistan in einer Patt-Situation. (SZ, 9, 11.01.2017, 7)

С обзиром на то да поменуте именице (Beobachter/cвједок) представљају уопштене агенсе или се ближе одређују атрибутима у генитиву чија се идентификација вјешто избјегава уопштеним сложеницама, као нпр. 23.) Beobachtung der Marketingfachleute, овакви уопштени модални извори само привидно поткрепљују истинитост пропозитивног садржаја и имају за циљ да манипулативно дјелују на реципијента.

Новинар користи често у новинским извјештајима на српском језику именицу свједок у функцији предикатива када се поистовјећује у трећем лицу множине заједно са реципијентом у својству свједока одређеног догађаја. Управо ова специфичност приказивања реципијента као свједока, представља пропозитивни садражај као општепознату чињеницу, која дјелују вјеродостојније и аутентичније, као нпр:

\section{Тврдња}

18. Рок је био 31.децембар 2009, али сведоци смо да се до данас ништа битно није променило. (По, 36474, 29.05.2015, 29)

19. Сведоци смо забрињавајућег нарастања неофашизма и неонационализма у Европи.... [...](По, 36474, 29.05.2015, 11) 
Будући да се новинар употребом трећег лица множине приказује као члан заједнице којој припада заједно са реципијентом, пропозитивни садржај се представља као чињеница коју су сви имали на увиду.

\section{3. ЗАКЉУЧАК О ИМЕНИЦАМА КОЈЕ ИЗРАЖАВАЈУ ИНДИРЕКТНУ ЕПИСТЕМИЧКУ МОДАЛНОСТ У НОВИНСКИМ ИЗВЈЕШТАЈИМА НА СРПСКОМ И ЊЕМАЧКОМ ЈЕЗИКУ}

Именице које означавају индиректну епистемичку модалност припадају у оба језика, која смо подвргли контрастирању, најчешће девербативним именицама, изведеним од глаголске основе из скупине верба диценди. Именице са индиректним епистемичким значењем користе се у оба језика у пропагандне сврхе извјештавања, тј. у сврху манипулативног убјеђивања и ограђивања, али и као референцијални, деиктички елементи који упућују на дијелове претходно споменутог исказа. Ова скупина именица јавља се у српском и њемачком језику са идентичним илокутивним функцијима (саопштења соградом/mвр$\underline{\partial њ a})$ и једино се разликује по фреквентности јављања појединих чланова и морфо-синтаксичкој реализацији у новинским извјештајима. За разлику од глагола из поменуте скупине, који пресупонирају пропозициони садржај као аргумент и примарни модални извор, уз девербативне именице модални извор је редундантна информација, која се губи номинализацијом глаголске основе, док се пропозитивни садржаји јављају уз поменуте именице, у оба језика, у виду да-реченице у функцији атрибута. Међутим, у новинским извјештајима у њемачком језику до изражаја долази много већа морфосинтаксичка зависност ове скупине именица, односно појава унутар надређених приједлошких фраза

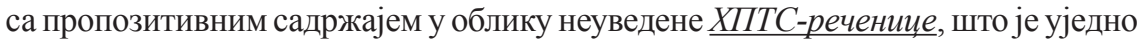
и најупечатљивија разлика за језички пар српско-њемачки. Именице са индиректним епистемичким значењем доприноси економичности и повезаности самог саопштења, експлицирају пропозитивни садражај у облику да-реченице, односно у њемачком језику фрекветније у виду неуведених XITC-реченица, и сматрају се једном од главних одлика новинских извјештаја.

\section{ИЗВОРИ:}

(ГС) - Глас Српске, од 10.04.2015;

(ФАЗ) - Франкфуртер аллгемајне цајтунг (Frankfuter Allgemeine Zeitung), од 29.05.2015, и 11.01.2017;

(СД) - Сиддоче цајтунг (Süddeutsche Zeitung), од 10.04.2015. и 29.05.2015;

(По) - Политика, од 29.05.2015. и 10.01.2017. 


\section{ЛИТЕРАТУРА}

Аксић 2014: Катарина Аксић, Елементи језика глобализације у политичком дискурсу Вука Јеремића, у: Зборник радова са научног скупа Наука и глобализација, Књига 8, том 1/1. Пале: Филозофски факултет Универзитета у Источном Сарајеву, 259-267.

Бабић 2012: Миланка Бабић, Епистемичка модалност у дневној штампи Републике Српске, у: Српски језик, књижевност, уметност, Крагујевац: Филум, 116-127.

Бабић 2002: Stjepan Babić, Tvorba riječi u Hrvatskome književnome jeziku, Zagreb: Nakladni Zavod Globus, Hrvatska Akademija znanosti u umjetnosti.

Доналис 2005: Elke Donalies, Die Wortbildung des Deutschen, Tübingen: Gunter Narr Verlag.

Дуден 1996: Duden, Deutsches Universalwörterbuch, Mannheim, Leipzig, Wien, Zürich: Dudenverlag.

Енгел 2004: Ulrich Engel, Deutsche Grammatik. München: IUDICUM Verlag $\mathrm{GmbH}$.

Катнић Бакаршић 1999: Marina Katnić-Bakaršić, Lingvistička Stilistika, Budimpešta: Open Society Institute.

Клајн 2003: Иван Клајн, Творба речи у савременом српском језику. Други део: суфиксаиија и конверзија. Београд - Нови Сад: САНУ.

Максимовић 2016: Јелена Максимовић, Језичко-стилске карактерситике новинске вести и новинског извештаја, Крагујевац: Филум. (Необјављена докторска дисертација)

Пипер и др. 2005: Предраг Пипер и др., Синтакса савременог српског језика. Београд: Институт за српски језик-САНУ.

Радовановић 1977: Милорад Радовановић, Декомпоновање предиката, Јужнословенски Филолог, 33, 53-80.

PCJ 2007: Речник српског језика, Нови Сад: Матица Српска.

Флајшер 1969: Wolfgang Fleischer, Wortbildung der deutschen Gegenwartssprache, Lepzig.

Флајшер/Барц 1995: Wolfgang Fleischer, Irmhild Barz, Wortbildung der deutschen Gegenwartssprache, Tübingen: Max Niemeyer Verlag. 


\section{KONTRASTIVEN ANALYSE VON NOMINA MIT INDIREKTER EPISTEMISCHER BEDEUTUNG IN DEN ZEITUNGSBERICHTEN}

\section{Zusammenfassung}

In der vorliegeden Arbeit haben wir uns mit Nomina mit indirekter epistemischer Bedeutung in der deutschen und serbischen Pressesprache beschäftigt. Nomina mit indirekter epistemischer Bedeutung haben in beiden Sprachen eine hohe Verwendung und werden in der linguistischen Literatur als Spezifkum der Pressesprache bezeichnet. Der Journalist verwendet die vorerwähnten Nomina hauptsächlich mit zwei manipulativen Zielen, dem Ziel a) der Distanzierung vom propositionalen Gehalt oder b) der Überzeugung des Reziepenten, dass der propositionale Gehalt der Wahrheit entspricht. Die Ergebnisse unserer Korpusanalayse haben gezeigt, dass die Nomina in beiden Sprachen die gleiche morpho-syntaktische Struktur haben können und da-/dass- Sätze regieren, aber auch gewisse Spezifika in den beiden Sprachen aufweisen. Nomina mit indirekter epistemischer Bedeutung kommen zwar mit der gleichen illokutiven Funktion in den Zeitungsberichten vor (Äußerung mit Distanz/Behauptung), weisen aber auch syntaktische Unterschiede auf. Der propositive Gahalt kommt in der serbischen Sprache am häufigsten in Form von dass-Sätze vor, während in der deutschen Sprache die Nomina mit indirekter epistemische Bedeutung eine starke Abhägigkeit von Präposionalphrasen zeigen und den propistionalen Gehalt öfters in Form von uneingeleiteten HPTS-Sätzen regieren.

Schlüsselwörter: manipulativen Strategie, Deverbativa, Überzeugung, Distanzierung, epistemische Modalität

Mladen D. Papaz

Ružica Zeljko-Zubac 